\title{
Ks. Waldemar Chrostowski, Między Synagogqa a Kościołem. Dzieje św. Pawła, Wydawnictwo M, Apostolicum, Kraków-Ząbki 2015, 500 s.
}

\author{
Michał Liana \\ Uniwersytet Pedagogiczny im. Komisji Edukacji Narodowej w Krakowie \\ mchliana@gmail.com (1) https://orcid.org/0000-0002-7985-4919
}

O życiu i działalności Pawła z Tarsu napisano wiele, jednak zagadnienie stosunków rodzącego się Kościoła i Synagogi widziane przez pryzmat nauczania Apostoła Narodów to temat jeszcze słabo zbadany w literaturze polskiej. Większość biografii św. Pawła skupia się wyłącznie na analizie zmian zachodzących we wczesnym chrześcijaństwie, pomijając istotny aspekt polityki żydowskiej wobec judeo- i poganochrześcijan, a także stosunek do nowatorskiej ewangelizacji prowadzonej przez Pawła. Właśnie szczegółowej egzegezie postawy Synagogi i Kościoła wobec nauczania Pawła poświęcone jest dzieło ks. prof. Waldemara Chrostowskiego - teologa i biblisty, znanego działacza na rzecz dialogu katolicko-żydowskiego, który jako pierwszy Polak otrzymał Nagrodę Ratzingera.

Na wstępie autor recenzowanej pracy zaznacza, że głównym źródłem jego pracy są Dzieje Apostolskie i Listy św. Pawła, które uważa za niezbędne do odtworzenia życiorysu Pawła z Tarsu, uważając za „bezużyteczne, szkodliwe, nowinkarskie i jałowe” publikacje ignorujące pisma Nowego Testamentu. Pisząc o swoich metodach pracy badawczej, zaznacza, że nie wdaje się w szczegółowe analizy filologiczne, socjologiczne i psychologiczne, nie zamierza także udowadniać historyczności narracji Dziejów Apostolskich ${ }^{1}$. Autor otwarcie mówi, że pisze z punktu widzenia chrześcijanina i nie odrzuca wpływu objawień Pawła jako decydującego czynnika jego dalszych losów: „Nie do przyjęcia jest taka zasada hermeneutyczna, która by z góry zakładała, iż to, co duchowne, nie istnieje bądź nie ma żadnego rzeczywistego wpływu na nasze życie. Takie założenie przekreśla wszelkie sensowne poruszanie się po obszarze

1 W. Chrostowski, Między Synagogą a Kościołem. Dzieje św. Pawła, Kraków-Ząbki 2015, s. 15. 
spraw duchownych i religijnych”2. Według niego opieranie się na pismach natchnionych nie umniejsza naukowości jego pracy: „życie, losy i pisma Pawła z Tarsu stanowią fundament, który zabezpiecza przed uleganiem politycznej i teologicznej poprawności, a tym samym przed fałszywie pojętą tolerancją i rezygnacją z integralnej wiary w Jezusa jako Mesjasza i Boga”3. Negowanie żydowsko-chrześcijańskiego konfliktu polityczno-religijnego bądź przemilczenie istotnych aspektów dotyczących prześladowania Kościoła Pawłowego przez Żydów sprawia, że obraz chrystianizacji Azji Mniejszej, Grecji i Italii staje się nie tylko niepełny, ale fałszywie relacjonuje wydarzenia w czasie podróży misyjnych i uwięzienia Pawła ${ }^{4}$.

Układ pracy jest podobny do innych biografii Pawła. Narracja rozpoczyna się od najmłodszych lat świętego, a także charakterystyki geopolityczno-społecznej i religijnej ówczesnego Lewantu, a także działalności faryzejskiej Pawła. Badacz przechodzi następnie do nawrócenia Pawła, działalności misyjnych, aby wreszcie zakończyć swoje dzieło na męczeńskiej śmierci Pawła w Rzymie. Podróże misyjne św. Pawła zajmują lwią cześć pracy, warto więc zwrócić uwagę na specyficzny sposób opisu stosowany przez autora. Ks. prof. Chrostowski, opisując podróże Pawła, drobiazgowo ujmuje

2 Tamże, s. 373. Ks. Chrostowski krytykuje między innymi bagatelizowanie epizodu z oślepieniem Pawła przez uczonych, którzy negując możliwość wpływu przeżyć religijnych, upatrywali w nim czynników czysto medycznych, np. epilepsji (tamże, s. 46).

3 Tamże, s. 16.

4 Niemiecki badacz Joachim Gnilka powściągliwie wypowiada się o udziale Synagogi w prześladowaniu Pawła. Winą za gnębienie Apostoła Narodów obarcza władze rzymskie i bliżej nieokreślonych obywateli wrogo nastawionych do nowej wiary (por. J. Gnilka, Paweł z Tarsu. Apostoł i świadek, przekł. W. Szymona, Kraków 2001, s. 115). Co więcej, w niechęci prokonsula Achai Galliona do rozstrzygnięcia sporu religijnego pomiędzy diasporą żydowską a Pawłem upatruje się antysemityzmu rzymskiego urzędnika, pomijając przy tym intencje prześladowców i zasadę niewtrącania się w sprawy religijne przez sądownictwo rzymskie (tamże, s. 171, więcej o oskarżeniu Pawła przed Gallionem: Richard Dillon, 1 List do Tessaloniczan, [w:] Katolicki komentarz biblijny, red. nauk. wyd. oryg. R. E. Brown, J. A. Fitzmyer, R. E. Murphy, red. nauk. wyd. pol. W. Chrostowski, Warszawa 2001, s. 1232; B. Winter, Rehabilitating Gallio and his judgement in Acts 18:14-15, „Tyndale Bulletin” 57 (2006) nr 2, s. 304-307). Ks. Chrostowski stanowczo przeciwstawia się „wybielaniu" Sanhedrynu w najnowszej literaturze, która za skazanie na śmierć Jezusa z Nazaretu obwinia Rzymian i stara się za wszelką cenę kwestionować historyczność udziału Żydów w męce Pańskiej (Waldemar Chrostowski, Między Synagogą a Kościołem, dz. cyt., s. 33). Mimo uzasadnienia autora, że odpowiedzialnością za śmierć Chrystusa nie można obarczać wszystkich Żydów, tylko tych, którzy bezpośrednio brali udział w skazaniu Go na śmierć krzyżową, niektórzy publicyści i autorytety kościelne dopatrują się w krytycznym pojmowaniu dialogu chrześcijańsko-żydowskiego przez ks. Chrostowskiego przejawów antysemityzmu (Marcin Stanowiec, Życiński sekuje ks. prof. Chrostowskiego, http://www.kosciol.pl/article.php/20090402022212574, 25.04.2017). 
zagadnienie komunikacji w starożytności, bierze pod uwagę topografię, warunki klimatyczne, charakterystykę społeczności zamieszkującej opisywane tereny, kulturę oraz trakty handlowe (wykorzystywane w przeprawach morskich i podróżach lądowych przez Apostoła Narodów), które później miały przełożenie na rozkrzewianie wiary Chrystusowej w Azji Mniejszej oraz Grecji i Macedonii ${ }^{5}$. W dziele ks. Chrostowskiego możemy spotkać wiele „smaczków” mających urozmaicić i zainteresować czytelnika omawianymi miejscami pobytu świętego - opisuje historię miast od najdawniejszych dziejów do czasów współczesnych ${ }^{6}$, często wspomina Polaków biorących udział w badaniach archeologicznych w miejscach pobytu Pawła7 . Warto dodać, że autor podaje informacje w sposób przystępny, tłumaczy podstawowe pojęcia związane z historią starożytną i teologią, dzięki czemu jego pracę można polecić również amatorom bardziej zainteresowanym działalnością Pawła z Tarsu. Godne pochwały jest zwrócenie uwagi na oceanografię fizyczną: kierunki wiatrów, okresów żeglugowych na Morzu Śródziemnym oraz nomenklatury używanej przez Łukasza Ewangelistę w Dziejach Apostolskich ${ }^{8}$. W Między Synagoga a Kościołem znajdujemy analizę psychologiczną trudnego charakteru Pawła z Tarsu, który zdaniem autora nieraz dawał się we znaki współtowarzyszom jego wypraw misyjnych ${ }^{9}$, a także parokrotnie nawiązywanie do rzekomego antyfeminizmu Pawła, który ks. Chrostowski całkowicie neguje, podkreślając bariery i szok kulturowy przeżyty przez Apostoła Narodów w czasie nauczania na zachodzie rządzącym się bardziej zliberalizowanymi obyczajami w stosunku do kobiet, akcentując ogromną (niekiedy nawet przewodnią) rolę kobiet $\mathrm{w}$ powstawaniu pierwszych gmin chrześcijańskich ${ }^{10}$.

Najważniejszą częścią publikacji pozostają jednak rozdziały poświęcone pedagogice ewangelizacyjnej św. Pawła, przedstawiające podejście dawnego prześladowcy do poganochrześcijan nienależących do Synagogi, wychowanych w kulturze i kultach pogańskich, a także stosunek Żydów do działań chrystianizacyjnych podejmowanych przez Pawła w pierwszej kolejności w synagogach diaspory. Autor nawiązuje do współczesnej polityki Kościoła

5 W. Chrostowski, Między Synagogą a Kościołem, dz. cyt., s. 78 i 94.

6 Tamże, s. 62

7 Prace archeologiczne na Cyprze prowadzone przez prof. Kazimierza Michałowskiego w roku 1965 i dr. Henryka Meyzę w roku 2008 (tamże, s. 98).

8 Tamże, s. 323 i 437.

9 Konflikt z Barnabą i Janem Markiem w czasie drugiej wyprawy misyjnej (tamże, s. 164), niewyjaśnione przyczyny rozstania z Sylasem w Koryncie (tamże, s. 241).

10 Tamże, s. 271. 
katolickiego, czerpiącej z narzędzi stosowanych przez Pawła w celu ewangelizowania ludności niechrześcijańskiej, ukazującej tym samym dziedzictwo nauczania Apostoła Narodów w dzisiejszym świecie. Paweł „nie potępia ani nie wyśmiewa pogan, ani wierzeń. [...] Jest to jedna z najstarszych katechez zawierających najważniejsze elementy chrześcijańskiej teologii religii pogańskich, stanowiącej nowotestamentowe pogłębienie dla deklaracji II Soboru Watykańskiego Nostra aetate o stosunku Kościoła do religii niechrześcijańskich ${ }^{11}$ ". Paweł jest świadomy różnic pomiędzy kandydatami na pogano- i judeochrześcijan - w swoim nauczaniu używa metafor i nawiązań do kultury antycznej zrozumiałej dla pogan niewywodzących się z kręgów żydowskich, dzięki czemu udaje mu się przekonać nie tylko pogan do nowej wiary, ale także uczestników soboru jerozolimskiego do zniesienia obciążania neofitów nie-żydów obowiązkiem przestrzegania Prawa żydowskiego ${ }^{12}$. Sukcesy ewangelizacyjne Pawła wśród pogan nie miały odbicia w próbach nawrócenia ludności żydowskiej. Zdaniem autora to właśnie rodacy Pawła byli głównymi prześladowcami apostoła, mimo że zawsze w pierwszej kolejności do nich kierował swoje nauki ${ }^{13}$. Pomimo początkowego zainteresowania chrześcijaństwem pogłębiały się antagonizmy nie tylko pomiędzy poganochrześcijanami i Żydami, ale także w samej diasporze - judeochrześcijanami i Żydami wiernymi religii przodków, którzy dla obrony wspólnoty żydowskiej, tradycji, obyczajów i interesów grupy gotowi byli współpracować z poganami celem prześladowania swoich rodaków ${ }^{14}$. Ks. prof. Chrostowski stanowczo przeciwstawia się teorii obarczającej za pogarszanie się relacji między chrześcijanami a Żydami wyłącznie chrześcijan, na której potwierdzenie „przytacza się - prawdziwe, domniemane, wyolbrzymione lub wyimaginowane - przykłady zaczerpnięte z historii obustronnej koegzystencji w późniejszych stuleciach, rzutując je na najwcześniejszy okres kształtowania się chrześcijaństwa. Uleganie tej modzie, za którą najczęściej stoją rygory politycznej poprawności, prowadzi do całkowitego zafałszowania sytuacji istniejącej do roku 70”15. Ks. Chrostowski zaznacza, że ciągłe poszukiwanie winy w stronie chrześcijańskiej prowadzi

11 Tamże, s. 126.

12 Tamże, s. 327.

13 D. H. Stern, Komentarz żydowski do Nowego Testamentu, Warszawa 2004, s. 504.

14 W. Chrostowski, Między Synagogą a Kościołem, dz. cyt., s. 59.

15 Tamże, s. 317. 
do absurdalnych sytuacji, jak np. traktowanie 1 Listu do Tesaloniczan jako antysemickiego i sugerowanie usunięcia go z kanonu ksiąg świętych ${ }^{16}$.

Praca ks. Chrostowskiego zapełnia lukę w literaturze problematyki stosunków żydowsko-chrześcijańskich w nauczaniu Pawła z Tarsu. Uważam ją za dzieło mające istotny wkład w polską naukę zajmującą się dziejami wczesnego chrześcijaństwa, pozwalające zrozumieć intencje i przemiany w społeczności chrześcijańskiej i żydowskiej, przyczyny i dalszy rozwój konfliktów wśród tych dwóch grup, które można polecić zarówno badaczom, jak i amatorom chcącym poszerzyć swoją wiedzę w tym zakresie. Mimo świadomego wyboru pozbawienia pracy odnośników do literatury przedmiotu i bibliografii liczącej zaledwie 40 wybranych przez autora pozycji, ubolewam nad brakiem aparatu naukowego, który z pewnością sprawiłby że praca ta stałaby się jeszcze bardziej wartościowa (być może autor chciał zapobiec rozrośnięciu się jego pracy do rozmiarów zmuszających do wydania jej w dwóch tomach). Na pochwałę zasługują jednak czytelne i dokładne mapy przedstawiające Ziemię Świętą w czasach Pawła, podróże misyjne oraz podróż do Rzymu. Pomimo tych drobnych mankamentów świetnie napisany tekst, wyjątkowy pogląd autora na sytuację konfliktu Synagoga-Kościół z pewnością skłonią wielu czytelników do sięgnięcia po dzieło ks. prof. Waldemara Chrostowskiego. 